Bojan Blagojević

Univeryitet u Nišu, Filozofski fakultet
УДК 378.147:17]:316.64-057.875

Оригинални научни рад

Примљено: 22. 10. 2020.

https://doi.org/10.46630/gflz.3.2021.04

\title{
UTICAJ KURSEVA IZ ETIKE NA MORALNE INTUICIJE STUDENATA FILOZOFIJE
}

\begin{abstract}
Apstrakt: $\mathrm{U}$ radu analiziramo deo rezultata istraživanja sprovedenog u okviru projekta „Uticaj kurseva iz filozofije na stavove studenata“ koji se tiče uticaja kurseva iz Istorije etike na moralne intuicije studenata druge godine filozofije na Filozofskom fakultetu u Nišu. Studenti su u dva navrata (pre i nakon slušanja kurseva) procenjivali tvrdnje koje su im date u specijalno napravljenom upitniku. Analizom eventualnih promena u odgovorima koje su studenti davali, pokušavamo da utvrdimo da li su kursevi koje su u međuvremenu pohađali doveli do značajne promene u njihovim moralnim intuicijama.
\end{abstract}

Ključne reči: etika, moralne intuicije, istraživanje, nastava

\section{Uvod}

Ovaj rad je nastao kao deo rezultata projekta „Uticaj kurseva iz filozofije na stavove studenata"1 koji je sproveden 2018/19. godine (sa nastavkom u 2019/20. godini). Cilj projekta je bio da ispita da li i u kolikoj meri univerzitetski (specifično filozofski) kursevi koji se sprovode na Departmanu za filozofiju Filozofskog fakulteta u Nišu utiču na formiranje raznih (pretežno vrednosnih) stavova studenata. Konkretnije, ovaj rad će izložiti rezultate ispitivanja vezanog za kurseve iz Istorije etike koje su ispitivani studenti slušali tokom akademske 2018/19. godine. Da bismo to učinili, prvo ćemo izložiti osnovne hipoteze istraživanja i definisati pojmove kojima se $u$ istraživanju bavimo. Nakon toga ćemo prezentovati navedene kurseve, kako sa njihove sadržinske, tako i sa didaktičko-metodičke strane. Zatim ćemo predstaviti dobijene rezultate. Konačno, u zaključnom poglavlju ćemo ponuditi interpretaciju rezultata i ponuditi dalji tok istraživanja.

\section{Osnovni pojmovi, hipoteze i metodologija istraživanja}

a) Moralne intuicije i zašto se njima baviti

Moralnim intuicijama nazivamo nereflektovane moralne stavove koje poseduje svaki moralno uračunljivi pojedinac. To su vrednosni stavovi koje ne formiramo na osnovu promišljanja ili dedukovanja iz opštih moralnih principa, već najčešće služe kao „kamen za ispitivanje“ različitih teorija morala. Tako, npr. možemo imati moralnu intuiciju da je pogrešno spaljivati žive bebe a ne biti u stanju da pružimo bilo kakvu potporu za taj stav (barem dok od nas ne traže da je ekspliciramo). To ne znači da

\footnotetext{
${ }^{1}$ Interni projekat Departmana za filozofiju Filozofskog fakulteta Univerziteta u Nišu, broj 183/1-16-4-01.
} 
vlada opšte slaganje po pitanju pouzdanosti intuicija. Razne verzije utilitarizma i deontološke etike smatraju da se na intuicije ne bi trebalo oslanjati, već da njihova vrednost zavisi od njihove konzistentnosti sa implikacijama dotičnog etičkog sistema. Rols (Rawls) u svojoj Teoriji pravde (A Theory of Justice) nudi metod reflektivne ravnoteže kojim možemo uskladiti naše snažne moralne intuicije (dovoljno snažne da od njih ne možemo odustati) sa moralnim principima koje prihvatamo. Neke od moralnih intuicija koje posedujemo će biti dovoljno snažne da nas nateraju da modifikujemo ili čak odustanemo od principa koje smo do tada prihvatali; druge će morati da ustuknu pred implikacijama principâ kojima smo naročito privrženi. Smatramo da je trenutak kada se studenti prvi put susreću sa kursevima iz etike značajan za ovaj proces. Očekivali smo da će izlaganje i analiza najznačajnijih etičkih sistema u istoriji filozofije značajno uticati na proces menjanja ili odbacivanja moralnih intuicija kod studenata.

\section{b) Metodologija istraživanja}

Ispitivanje kojim se bavimo ima za cilj da utvrdi da li i u kolikoj meri kursevi iz Istorije etike mogu promeniti moralne intuicije studenata koji ih pohađaju. $\mathrm{Za}$ ispitanike smo uzeli studente druge godine; testovi su vršeni pre i nakon dva semestra pohađanja kurseva (na početku jesenjeg i na kraju prolećnog semestra akademske 2018/19. godine). Imajući u vidu sadržinu kurseva (o čemu će biti reči u narednom poglavlju), naša početna hipoteza je da ti kursevi utiču na promenu moralnih intuicija studenata. Da bismo utvrdili i izmerili taj uticaj, studentima je dat identičan test sa 12 moralnih tvrdnji (od ukupno 66 tvrdnji); od studenata se tražilo da zaokruže broj na skali od 1 do 5 , pri čemu je 1) označavalo stav „uopšte se ne slažem“, 2) „većinom se ne slažem“, 3) „nisam siguran/-na“, 4) „većinom se slažem“ i 5) ,u potpunosti se slažem“. Studentima su date instrukcije da ne postoje tačni i netačni odgovori, tj. više i manje adekvatne ocene datih tvrdnji, te da na date tvrdnje treba da odgovore bez mnogo promišljanja, kako bi se zaista radilo o nereflektovanom stavu. Broj ispitanika (osam studenata druge godine filozofije) mali je, te smo svesni da je za dobijanje pouzdanijih rezultata neophodno nastaviti ispitivanje i u narednim godinama.

Moralne tvrdnje koje su studenti u okviru testa ocenjivali su:

Tvrdnja 4: Uvek treba poštovati moralna uverenja drugih ljudi.

Tvrdnja 11: Svi ljudi su po prirodi egoisti.

Tvrdnja 17: Ljude u moralnom pogledu procenjujem na osnovu njihovih namera. Tvrdnja 20: Za oblikovanje karaktera najvažnije su nasledne osobine.

Tvrdnja 23: Dopušteno je da radim sve što hoću dok time ne povređujem druge ljude. Tvrdnja 30: Preljuba nije nemoralna ako se za nju ne sazna.

Tvrdnja 36: Postoji jedan jedini moral koji važi za sve ljude.

Tvrdnja 43: Bez boga sve bi bilo dopušteno.

Tvrdnja 49: Pre delanja uvek treba razmišljati o posledicama.

Tvrdnja 54: Oslanjam se na osećanja pri moralnom procenjivanju.

Tvrdnja 59: Moral je u najvećoj meri genetski određen.

Tvrdnja 63: Dopušteno je oduzeti život nevinoj osobi ukoliko bi to spasilo život većem broju takođe nevinih osoba. 
U narednim poglavljima ekspliciraćemo fokus svake od ovih moralnih tvrdnji.

Promene u moralnim intuicijama merićemo tako što ćemo izračunati razliku između odgovorâ na prvom i drugom testu, ne uzimajući u obzir predznak (dakle, promena od odgovora „1" ka odgovoru „3“ će biti uzeta u obzir podjednako kao promena od odgovora „3“ "ka odgovoru „1“, budući da nas prvenstveno interesuje samo promena intuicije, a ne i njen smer). Budući da su testovi bili šifrirani (i anonimni), moguće je pratiti promenu u odgovorima svakog studenta ponaosob. Budući da je broj ispitanika jako mali, ovakvo praćenje promene u intuicijama može biti korisnije od kvantitativne analize čitavog (oskudnog) uzorka.

\section{Kursevi iz etike}

Naše istraživanje se bavi uticajem kurseva koje studenti slušaju tokom druge i treće godine studiranja. Na drugoj godini, prema programu akreditovanom 2014. godine, to su Istorija etike 1 (3. semestar) i Istorija etike 2 (4. semestar), a na trećoj godini Sistematska etika 1 (5. semestar) i Sistematska etika 2 (6. semestar). Budući da je cilj istraživanja da uporedi moralne intuicije pre i nakon slušanja tih kurseva, studenti treće godine su bili već „iskvaren“ uzorak, budući da su prethodna dva semestra slušali nastavu iz Istorije etike. Zato smo odlučili da za početak ovog istraživanja uzmemo u obzir samo studente druge godine (koji će biti testirani još jednom, nakon što odslušaju i kurseve iz Sistematske etike).

Kursevi iz Istorije etike su obavezni kursevi na departmanu za filozofiju, sa po 2 časa predavanja i vežbi nedeljno i nose po 6 ESPB. Budući da u našim srednjim školama nema obavezne nastave iz etike (a najčešće je uopšte i nema), jedini kontakt koji studenti imaju sa tom filozofskom disciplinom pre slušanja kursa iz Istorije etike jesu srednjoškolska nastava iz filozofije (ako je imaju) i odeljak posvećen etici u Erlovom Uvodu u filozofiju², koji je obavezna literatura iz kursa Uvod u filozofiju, koji se sluša na prvoj godini studija.

Što se tiče sadržine kurseva, Istorija etike 1 pokriva razdoblje od presokratske etičke misli do Prosvetiteljstva, dok Istorija etike 2 otpočinje sa Kantom i završava sa savremenim teorijama morala.

Najviše pažnje u okviru kursa Istorije etike 1 posvećuje se etičkoj misli Sokrata, Platona i Aristotela, i u okviru toga pojmovima vrline, prirode, dobrog života, zatim praktičkoj misli Moderne u kojoj se moralno rezonovanje odvaja od hrišćanskog teonomnog zasnivanja i usmerava ka usklađivanju pojedinačnih interesa i legitimnih zahteva zajednice (uključujući tu i razmišljanja o samom procesu te legitimacije). Na časovima vežbi obrađuju se delovi Platonovih dijaloga „Protagora“, „Gorgija“, Države, Aristotelove Nikomahove etike, Rusoovog Društvenog ugovora.

Najveća pažnja u okviru kursa Istorije etike 2 posvećuje se Kantovoj etici dužnosti, i u okviru toga pojmovima slobode, uma, univerzalnog moralnog zakona, zatim na etičkim teorijama $18-$ og i 19-og veka koje počivaju na kritici Kantove eti-

\footnotetext{
${ }^{2}$ V.Dž.Erl, Uvod u filozofiju, Dereta, Beograd, 2005.
} 
ke, utilitarizmu, počecima savremene metaetike. Na vežbama se obrađuju Kantovo Zasnivanje metafizike morala i Kritika praktičkog uma i delovi Ničeove Genealogije morala. Usled asimetrije prisutne u korist etike dužnosti, a nauštrb utilitarizma očekujemo da će rezultati istraživanja pokazati promenu stavova studenata u smeru deontologije (bar kod onih tvrdnji gde se radi o dihotomiji konsekvencijalizam-deontologija).

Kursevi su u didaktičko-metodičkom smislu usmereni na to da osposobe studente da etičke pozicije i argumente kako analiziraju i kritikuju, tako i da ih kontekstualizuju, uviđaju uslove njihovog nastanka, promene, gubljenja uticaja. Poseban naglasak je stavljen na način na koji etičke teorije ovog perioda oblikuju i današnju moralnu svest. Etika je u tom smislu zahvalna za ovu vrstu istraživanja, jer se tiče stavova koje poseduju bezmalo svi i do kojih nam je po pravilu stalo. Etički kursevi nas suočavaju sa problematizacijom tih stavova. Kako ćemo reagovati na to? Studenti mogu sasvim lepo naučiti lekcije, ispuniti sve što se traži od njih, a opet zadržati svoja uverenja iako uviđaju da su međusobno nekonzistentna, jer, kako je Nozik (Nozick) pokazao, konzistentnost je takođe stvar od koje se može podjednako dobro odustati. ${ }^{3}$ Ukoliko je na mestu tradicionalna pretenzija filozofije da može (i treba) da utiče na ljudski karakter, onda bismo očekivali da didaktičko-metodički uspešno realizovani kursevi iz etike ne budu viđeni tek kao gradivo koje se treba savladati kao npr. gradivo iz geografije ili biologije, već da „uvuku“ studente u proces problematizacije moralnih uverenja kao svojih uverenja.

\section{Rezultati istraživanja}

Rezultati istraživanja su prezentovani u Tabeli 1. U redovima su prikazane moralne tvrdnje na koje su ispitanici odgovarali. Kolone pokazuju odgovore osmoro ispitanika (petoro studenata muškog pola i troje ženskog pola). Ćelije tabele pokazuju rezultat na prvom i na drugom testiranju.

Prvo ćemo se okrenuti rezultatima dobijenim za svaku pojedinačnu tvrdnju, a zatim prezentovati zbirne rezultate.

\begin{tabular}{|l|c|c|c|c|c|c|c|c|}
\hline & M1 & Ž2 & M3 & M4 & M5 & M6 & Ž7 & Ž8 \\
\hline $\begin{array}{l}\text { tvrdnja 4: Uvek treba poštovati } \\
\text { moralna uverenja drugih ljudi. }\end{array}$ & $3>2$ & $5>4$ & $4>3$ & $5>4$ & $4>3$ & $3>1$ & $3>2$ & $1>2$ \\
\hline $\begin{array}{l}\text { tvrdnja 11: Svi ljudi su po prirodi } \\
\text { egoisti. }\end{array}$ & $4>4$ & $2>2$ & $1>2$ & $4>4$ & $2>2$ & $5>5$ & $3>3$ & $2>1$ \\
\hline $\begin{array}{l}\text { tvrdnja 17: Ljude u moralnom } \\
\text { pogledu procenjujem na osnovu } \\
\text { njihovih namera. }\end{array}$ & $2>4$ & $5>4$ & $4>3$ & $4>5$ & $3>5$ & $1>5$ & $2>4$ & $3>4$ \\
\hline $\begin{array}{l}\text { tvrdnja 20: Za oblikovanje karaktera } \\
\text { najvažnije su nasledne osobine. }\end{array}$ & $3>2$ & $4>1$ & $3>3$ & $1>2$ & $2>2$ & $3>1$ & $2>2$ & $1>2$ \\
\hline
\end{tabular}

\footnotetext{
${ }^{3}$ R. Nozick. Philosophical Explanations, Harvard University Press, Cambridge, 1981, str. 408.
} 


\begin{tabular}{|l|c|c|c|c|c|c|c|c|}
\hline $\begin{array}{l}\text { tvrdnja 23: Dopušteno je da radim } \\
\text { sve što hoću dok time ne povređujem } \\
\text { druge ljude. }\end{array}$ & $4>3$ & $4>5$ & $5>5$ & $1>1$ & $1>1$ & $5>5$ & $5>4$ & $2>1$ \\
\hline $\begin{array}{l}\text { tvrdnja 30: Preljuba nije nemoralna } \\
\text { ako se za nju ne sazna. }\end{array}$ & $3>1$ & $1>1$ & $2>4$ & $1>1$ & $2>1$ & $1>1$ & $1>1$ & $1>1$ \\
\hline $\begin{array}{l}\text { tvrdnja 36: Postoji jedan jedini moral } \\
\text { koji važi za sve ljude. }\end{array}$ & $3>4$ & $2>3$ & $1>1$ & $2>3$ & $5>4$ & $1>1$ & $1>2$ & $2>2$ \\
\hline $\begin{array}{l}\text { tvrdnja 43: Bez boga bi sve bilo } \\
\text { dopušteno. }\end{array}$ & $3>3$ & $1>1$ & $3>1$ & $2>4$ & $3>2$ & $5>1$ & $2>2$ & $1>1$ \\
\hline $\begin{array}{l}\text { tvrdnja 49: Pre delanja uvek treba } \\
\text { razmišljati o posledicama. }\end{array}$ & $5>4$ & $5>5$ & $4>3$ & $3>2$ & $3>4$ & $5>5$ & $5>4$ & $5>5$ \\
\hline $\begin{array}{l}\text { tvrdnja 54: Oslanjam se na osećanja } \\
\text { pri moralnom procenjivanju. }\end{array}$ & $3>3$ & $2>1$ & $3>3$ & $4>4$ & $3>4$ & $3>1$ & $3>4$ & $2>2$ \\
\hline $\begin{array}{l}\text { tvrdnja 59: Moral je u najvećoj meri } \\
\text { genetski određen. }\end{array}$ & $3>2$ & $1>1$ & $1>3$ & $2>3$ & $1>3$ & $3>1$ & $1>1$ & $1>1$ \\
\hline $\begin{array}{l}\text { tvrdnja 63: Dopušteno je oduzeti } \\
\text { život nevinoj osobi ukoliko bi to } \\
\text { spasilo život većem broju takođe } \\
\text { nevinih osoba. }\end{array}$ & $3>1$ & $1>1$ & $3>3$ & $3>1$ & $1>1$ & $5>5$ & $3>3$ & $1>3$ \\
\hline
\end{tabular}

Tabela 1: rezultati ispitivanja stavova studenata druge godine po pitanju moralnih tvrdnji

Tvrdnja 4: Uvek treba poštovati moralna uverenja drugih ljudi.

$\mathrm{Na}$ drugom testiranju je svih osmoro ispitanika dalo drugačiji odgovor u odnosu na prvi test, pri čemu je razlika kod sedmoro ispitanika bila 1, a kod jednog ispitanika 2. Odgovori sedmoro ispitanika su ispoljavali promenu ka povećanom neslaganju sa tvrdnjom, dok je odgovor samo jedne ispitanice promenjen ka povećanom slaganju. Prosečna vrednost odgovora se od 3.5 pomerila na 2.675. Najčešći odgovor prilikom prvog testiranja bio je 3, tj. „nisam siguran/-na“, (tri ispitanika je dalo taj odgovor), dok je pri drugom testiranju svo troje ispitanika promenilo odgovor ka neslaganju (dvoje ispitanika je odgovorilo sa 2, tj. „,većinom se ne slažem“, a jedan ispitanik sa 1 , tj. ,,uopšte se ne slažem“). Na drugom testu je najčešći odgovor bio 2 (troje ispitanika).

Tvrdnja je usmerena na probleme moralnog pluralizma i relativizma. Kako bi se promena u odgovorima mogla objasniti? S jedne strane, moralne intuicije pre slušanja etičkih kurseva bivaju formirane u kontekstu emotivističkih predubeđenja da je moral relativan ili čak „stvar ukusa“ i da pri procenjivanju moralnih sudova nema pozicije sa koje bismo mogli da tvrdimo da smo apsolutno u pravu; s druge strane, nelagodnost koju osećamo kada pokušavamo da to primenimo na neprihvatljive moralne pozicije, poput nacističke, izazivaju nesigurnost (otud najveći broj odgovora „nisam siguran/-na“ na prvom testu). Obrađujući na etičkim kursevima teorije kontraktualizma, utilitarizma i Kantovu etiku dužnosti studenti su se upoznali sa nekim osnovama pravljenja razlike između prihvatljivih i neprihvatljivih moralnih uverenja koji se razlikuju od našeg (npr. stav da smo dužni da poštujemo autonomiju drugih ljudi, ali da nismo dužni da poštujemo i sve izbore koje oni donesu). Stoga, razlike u njihovim odgovorima idu od nesigurnosti ka neslaganju sa tvrdnjom da uvek treba poštovati moralna uverenja drugih ljudi. 
Tvrdnja 11: Svi ljudi su po prirodi egoisti.

Po pitanju ove tvrdnje se odgovori sa drugog testa najmanje razlikuju od odgovora sa prvog. Samo dvoje od osmoro ispitanika je promenilo svoj odgovor za 1 (jedan u pravcu većeg slaganja - od 1 na 2 - a jedan u pravcu većeg neslaganja - od 2 na 1). Kursevi iz Istorije etike nisu izvršili uticaj na menjanje stavova ispitanika u ovom pogledu.

Tvrdnja 17: Ljude u moralnom pogledu procenjujem na osnovu njihovih namera.

Ispitanici su na drugom testu značajno promenili svoje odgovore po pitanju ove tvrdnje. Sve osmoro ispitanika je dalo drugačije odgovore u odnosu na prvi test. Od toga, četvoro je izmenilo svoj odgovor za 1, troje za 2, a jedan ispitanik je promenio svoj odgovor od 1 („uopšte se ne slažem“) na 5 („u potpunosti se slažem“). Prosečna vrednost odgovora se promenila sa 3 na 4,25. Na prvom testu je po dvoje ispitanika dalo odgovor 2, 3 i 4, dok je na drugom testu najčešći odgovor bio 5 (troje ispitanika). Šestoro ispitanika je promenilo svoj odgovor ka većem slaganju, a dvoje ka većem neslaganju.

Tvrdnja je usmerena na dihotomiju konsekvencijalizam-nekonsekvencijalizam (tj. na pitanje na osnovu čega procenjujemo moralni status nekog čina ili moralnu vrednost neke osobe). Odgovori na prvom testu ukazuju na generalnu neopredeljenost ispitanika (ovo je jedina od ponuđenih tvrdnji kod koje su zaista bili zastupljeni svi ponuđeni odgovori, od 1 do 5). Nakon odslušanih etičkih kurseva, vidna je promena ka nekonsekvencijalizmu. Sadržina etičkih kurseva može objasniti ovu promenu. Aristotelovo opravdanje kazne i zasluge i Kantov pojam dobre volje kao osnove moralnosti (pomenimo dve najznačajnije teme koje su u vezi sa pomenutom tvrdnjom) uključuju tezu da postupak i njegove posledice nisu adekvatan pokazatelj moralnog statusa jednog čina ni moralne vrednosti jedne osobe, te da je potrebno okrenuti se drugim pokazateljima na osnovu kojih bismo pouzdanije mogli zaključiti o karakteru/moralnoj vrednosti osobe. Pomenuta asimetričnost zastupljena u kursevima je dala upravo očekivane rezultate; možemo postaviti dalju hipotezu da bi kurs u kojem bi konsekvencijalističke teorije bile zastupljenije doveo do drugačije promene u odgovorima ispitanika. To bi dalje otvorilo pitanje o odgovornosti nastavnika za uticaj koji njegovi kursevi imaju na studente u ovom pogledu.

Tvrdnja 20: Za oblikovanje karaktera najvažnije su nasledne osobine.

Petoro ispitanika je na drugom testu promenilo odgovor u odnosu na prvi, od toga jedan ispitanik za 2, a jedna ispitanica za 3 (oboje u pravcu većeg neslaganja; na drugom testu je odgovor oboje ispitanika bio 1, tj. ,uopšte se ne slažem“). Prosečna vrednost odgovora na prvom testu je bila 2,375 , a na drugom 1,875 . Najčešći odgovor na prvom testu je bio 3, tj. „nisam siguran/-na“" (troje ispitanika), a na drugom testu $2, \mathrm{tj}$. „većinom se ne slažem“ (pet ispitanika).

Tvrdnja je usmerena na mogućnost menjanja karaktera i, posredno, na odgovornost koju ljudi imaju za svoj karakter (kao moralno relevantni deo njihove ličnosti). Obradom tekstova koji se tim problemom bave (Platonov „Protagora“, Aristotelova Nikomahova etika, te i Kantovo Zasnivanje i druga Kritika), studenti se upoznaju sa etičkim koncepcijama koje odbijaju ideju datosti karaktera i implikacijama te ideje. 
U odnosu na neodlučnost primetnu kod odgovora datim na prvom testu, nakon slušanja kurseva vidi se očekivana promena ka neslaganju sa datom tvrdnjom (od trojice ispitanika koji su u prvom testu dali odgovor 3, dvojica su promenila odgovor, jedan ka potpunom, drugi ka većinskom neslaganju). Jedina ispitanica koja se na prvom testu većinski saglasila sa tvrdnjom, na drugom testu je izrazila potpuno neslaganje.

Tvrdnja 23: Dopušteno je da radim sve što hoću dok time ne povređujem druge ljude.

Ovo je jedina tvrdnja kod koje nijedan ispitanik na prvom testu nije odgovorio sa 3 (a na drugom testu je samo jedan ispitanik dao taj odgovor). Prosečna vrednost odgovora na prvom testu je 3,375, a na drugom 3,125. Najčešći odgovor na prvom testu je 5 (troje ispitanika), a na drugom je po troje dalo odgovore 5 i 1.

Ova tvrdnja je usmerena na dva problema: slobodu pojedinca od koncepcije dobrog života koje mu nameće zajednica i postojanje moralne dužnosti prema sebi. $\mathrm{Na}$ etičkim kursevima su ovi problemi zastupljeni u odnosu antičke i moderne etike, ili u okviru moderne etike u sistemima Kanta, Šopenhauera, Mila (koji zagovaraju suprotne pozicije po pitanju ove tvrdnje). Budući da razlike u odgovorima nisu velike (četvoro ispitanika je promenilo svoje odgovore za 1, od toga troje ka većem neslaganju, jedna ka većem slaganju), nema indicije da su etički kursevi izvršili značajan uticaj. Stiče se utisak na osnovu odgovora sa prvog testa da su intuicije studenata već prilično snažno opredeljene po ovom pitanju te da se „priklanjaju“ onoj etičkoj teoriji koja u najvećoj meri može da te intuicije i opravda.

Tvrdnja 30: Preljuba nije nemoralna ako se za nju ne sazna.

Trojica ispitanika je promenilo odgovor u odnosu prvi test. Od toga, dvojica su promenila svoj odgovor za 2. Upadljivo je što je jedan od te dvojice ispitanika promenio svoj odgovor od 2, tj. „većinom se ne slažem“, na 4, tj. „većinom se slažem“, čime je postao jedini ispitanik koji na drugom testu nije odgovorio sa 1. Ostale promene su išle u pravcu potpunog neslaganja sa tvrdnjom. Najčešći odgovor i na jednom i na drugom testu je bio 1 .

Ova tvrdnja je usmerena na hedonističke/utilitarističke teorije mentalnih stanja, tj. na pitanje da li moralni status jednog čina zavisi od količine zadovoljstva/bola (shvaćenih kao mentalna stanja) koje aktualno dobijamo ili od njegovih svojstava koje on poseduje izvan naših mentalnih stanja. ${ }^{4}$ Iako se etički kursevi dotiču ovog problema od Platonovog „Gorgije“ i njegovog nastavka u kiničko-stoičkoj liniji, pa do savremenih kritika utilitarizma, ${ }^{5}$ nemamo osnova da pretpostavimo da utiču na stavove studenata, jer njihove prvobitne intuicije već ispoljavaju snažnu objektivističku tendenciju koja ne biva promenjena ni u odgovorima na drugom testu.

Tvrdnja 36: Postoji jedan moral koji važi za sve ljude.

U odnosu na prvi test, petoro ispitanika je promenilo odgovor za 1 , i to četvoro u smeru većeg slaganja, i jedan u smeru neslaganja. Dvoje ispitanika je od „većinom se ne slažem“ promenilo odgovor u „nisam siguran/-na“.

\footnotetext{
${ }^{4}$ S.Kagan, Normative Ethics, Westview Press, Boulder, 1998, str. 34-6.

${ }^{5}$ R. Nozick, Anarchy, State, Utopia, Basic Books, New York, 1974, str. 42-5.
} 
Pitanje se odnosi na postojanje univerzalnog morala. Na etičkim kursevima se analiziraju različite koncepcije koje zagovaraju univerzalni moral, bilo da je zasnovan na ljudskoj prirodi, praktičkom umu ili sposobnosti za doživljavanje zadovoljstva i bola, analiziraju se argumenti, implikacije i kritike tih koncepcija. Na rezultatima testa se ne vidi značajna promena stavova studenata nakon odslušanih kurseva.

Tvrdnja 43: Bez boga bi sve bilo dopušteno.

Četvorica ispitanika su promenila odgovor u odnosu na prvi test, od toga je razlika između odgovora kod dvojice ispitanika bila 2, a jedan ispitanik je na prvom testu dao odgovor 5, tj. ,u potpunosti se slažem“, a na drugom 1, tj. ,uopšte se ne slažem“. Nijedna od ispitanica nije promenila svoj odgovor. Samo jedan ispitanik je promenio svoj odgovor ka većem slaganju (od 2 na 4). Najčešći odgovor na prvom testu je bio 3 (,nisam siguran/-na“, tri ispitanika), a na drugom testu 1 (,,uopšte se ne slažem“, četiri ispitanika).

Tvrdnja je usmerena na poreklo morala i teonomne koncepcije. Obrađujući etičke teorije koje se ne zasnivaju na božanskim autoritetima, kao i one koje su uticale na formiranje hrišćanskog morala (u okviru kojeg i nastaje ova tvrdnja), studenti imaju priliku da kontekstualizuju ovu tvrdnju, procene njenu zasnovanost i sagledaju alternativne teorije. Odgovori na drugom testu ukazuju na smanjivanje neodlučnosti po pitanju ove tvrdnje (samo jedan od trojice ispitanika koji su na prvom testu dali odgovor 3 je zadržao taj odgovor i na drugom testu) i, što je očekivano, većinski porast neslaganja.

Tvrdnja 49: Pre delanja treba uvek razmišljati o posledicama.

Petoro ispitanika je na drugom testu dalo drugačiji odgovor povodom ove tvrdnje. Od toga, odgovor četvoro ispitanika se kretao ka većem neslaganju. Ipak, i nakon drugog testa, rezultati i dalje teže slaganju (prosečna vrednost odgovora se promenila sa 4,375 na 4; najčešći odgovor na prvom testu je 5 \{petoro ispitanika\}, dok je na drugom testu po troje ispitanika odgovorilo sa 4 i 5).

Ova tvrdnja je usmerena na stepen prihvatanja konsekvencijalizma. Prvobitne intuicije ispitanika pokazuju velik stepen prihvatanja značaja posledica jednog čina po njegov moralni status. I nakon odslušanih etičkih kurseva, odgovori ispitanika i dalje jako naginju ka slaganju sa ovom tvrdnjom, ali je stepen slaganja nešto niži, što je očekivano usled pomenute asimetričnosti zastupljene u sadržini kurseva.

Tvrdnja 54: Oslanjam se na osećanja pri moralnom procenjivanju

Četvoro ispitanika je na drugom testu promenilo svoj odgovor u odnosu na prvi, od čega je jedan ispitanik promenio odgovor za 2 (od „nisam siguran/-na“ na „uopšte se ne slažem“). Prosečna vrednost odgovora je skoro nepromenjena (od 2,875 na 2.75), ali je najčešći odgovor promenjen od 3, tj. „nisam siguran/-na“ (koji je na prvom testu dalo čak petoro ispitanika) na 4, tj. ,većinom se slažem“ (koji je na drugom testu dalo troje ispitanika). Od petoro ispitanika koji su na prvom testu odgovorili sa 3, dvojica ispitanika su zadržala taj odgovor i na drugom testu, dvoje ispitanika je odgovorilo sa 4 , a jedan ispitanik sa 1.

Tvrdnja je usmerena na osnov moralnih procena. Iako su na etičkim kursevima zastupljene i etičke teorije koje bi mogle podržati ovu tvrdnju (poput senti- 
mentalizma, emotivizma, Šopenhauerove etike samilosti), većina obrađenih teorija naglašavaju ulogu razuma/uma kao instance moralne procene. Kursevi su uticali na smanjenje nesigurnosti ispitanika po pitanju osnova donošenja moralnih sudova (od petoro nesigurnih, dvoje ispitanika se sada većinom slaže da sudove donose oslanjajući se na emocije, a jedan ispitanik se sa tim uopšte ne slaže). Ostaje problem vezan za formulaciju tvrdnje. Naime, tvrdnja je deskriptivna, a ne normativna, te se ne može videti stav ispitanika po pitanju toga da li oni s pravom donose svoje moralne procene na taj način.

Tvrdnja 59: Moral je u najvećoj meri genetski određen.

Svih pet ispitanika muškog pola je promenilo odgovor u odnosu na prvi test, od toga je kod trojice ispitanika razlika između odgovora 2. Prosečni odgovor se vrlo malo promenio: od 1,625 na prvom testu na 1,875 na drugom. Najčešći odgovor na oba testa je 1 . Sve ispitanice su na oba testa odgovorile sa 1.

Iako je ova tvrdnja gotovo identična tvrdnji 20, „Za oblikovanje karaktera najvažnije su nasledne osobine", odgovori ispitanika povodom ovih tvrdnji se znatno razlikuju, naročito na prvom testu. I na drugom testu je tek polovina ispitanika dala identičan odgovor povodom obe tvrdnje (ta razlika se ne može primetiti ukoliko se gledaju samo prosečne vrednosti odgovora).

Što se tiče promene odgovora ispitanika nakon slušanja etičkih kurseva, zanimljivo je da dvojica ispitanika koja su na prvom testu dala odgovor „,nisam siguran/na" sada izražavaju neslaganje sa ovom tvrdnjom (jedan potpuno, a jedan većinsko), a da su ostala trojica ispitanika koja su izražavala neslaganje na prvom testu (dvojica potpuno, jedan većinsko) na drugom testu dala odgovor „nisam siguran/-na“. Budući da su na etičkim kursevima obrađivane etičke teorije koje naglašavaju pojedinčevu odgovornost za sopstvenu moralnu vrednost, a da nisu bile zastupljene evolucionističke teorije, ova promena nije očekivana i ne može se objasniti uticajem kurseva.

Tvrdnja 63: Dopušteno je oduzeti život nevinoj osobi ukoliko bi to spasilo život većem broju takođe nevinih ljudi.

Samo troje ispitanika je promenilo odgovor u odnosu na prvi test, ali sve troje je na drugom testu dalo odgovor koji se od prvog razlikuje za 2. Prosečna vrednost odgovora se neznatno izmenila, od 2,5 na prvom testu na 2,25 na drugom. Najčešći odgovor na prvom testu je 3 (četvoro ispitanika), a na drugom 1 (četvoro ispitanika).

Tvrdnja je usmerena na dihotomiju konsekvencijalizam-nekonsekvencijalizam i u okviru toga, na opravdanost tzv. „kolateralne štete“. Već smo naveli da etički kursevi koje su studenti pohađali između dva testiranja obrađuju i konsekvencijalističke i nekonsekvencijalističke teorije, uz analizu i kritiku njihovih argumenata. Nakon slušanja kurseva, dvoje ispitanika koji su na prvom testu bili nesigurni su sada odgovorili sa 1. Jedna ispitanica koja je na prvom testu izrazila potpuno neslaganje, na drugom testu dala je odgovor 3. Primetniji je mali pomak ka nekonsekvencijalističkoj poziciji, ali se na osnovu odgovora ispitanika ne može zaključiti da su etički kursevi imali značajan uticaj na njihovu promenu (petoro ispitanika je dalo nepromenjene odgovore). 
Što se tiče rezultata ispitivanja u celini, od 96 odgovora ispitanika, 39 odgovora (38.5\%) je ostalo nepromenjeno, 57 (61.5\%) promenjeno je, a kod 19 odgovora (19.8\%) zabeležena je razlika od 2 ili više. Dodatna pretpostavka je bila da će usled pomenute asimetričnosti u sadržaju kursa doći do pomaka ka nekonsekvencijalističkim pozicijama kod tvrdnji koje se na to odnose. Ta pretpostavka se pokazala opravdanom jer se pri ocenjivanju tih tvrdnji, od 24 odgovora promenilo $16(66.7 \%)$, od čega 12 u smeru nekonsekvencijalističke pozicije, a od toga se 6 odgovora promenilo za 2 ili više.

\section{Zaključci}

Dva najveća problema ovog istraživanja jesu mali uzorak i nemogućnost provere/kontrole drugih faktora koji mogu uticati na promenu moralnih stavova (ovaj drugi problem bi svakako bar delimično izgubio na značaju sa povećanjem uzorka).

Imajući u vidu navedene probleme, smatramo da ipak imamo razlog za optimizam ukoliko se sa ovim istraživanjem nastavi, budući da početni rezultati ukazuju na znatne promene u moralnim intuicijama, najčešće upravo u onom smeru u kojem bi se mogle očekivati pod uticajem kurseva iz Istorije etike. Ukoliko se isti rezultati ponove i u nastavku istraživanja, odnosno, na većem uzorku, to bi svakako govorilo u prilog tradicionalnoj pretenziji filozofije da, pored toga što može osposobiti za kritičko mišljenje, može uticati i na karakter pojedinaca, odnosno u ovom slučaju, menjati njegove moralne intuicije.

Nije teško zaključiti kako bi ovakvi rezultati uticali na nastavu filozofije. Pre svega, valjalo bi dalje testirati i tezu da kursevi iz filozofije mogu imati sličan uticaj na studente drugih nauka ili srednjoškolce; zatim, prihvatiti odgovornost koju kao nastavnici i/ili autori kurikulumâ imamo u procesu oblikovanja vrednosnih stavova mladih ljudi u čijem obrazovanju učestvujemo. Konačno, ako etički kursevi mogu menjati moralne intuicije studenata, treba primetiti da oni to ne rade pukom prezentacijom sadržaja ili „moralisanjem“, već insistiranjem na analizi pozicija i argumenata i na kritičkom stavu na koji se studenti podstiču ne samo prema etičkim teorijama sa kojima se susreću već i prema samim intuicijama koje donose sa sobom. To je momenat kojim se ta vrsta uticaja razlikuje od indoktrinacije, koja konstantno vreba obrazovanje kao njegov zli dvojnik, preteći da neprimetno zauzme njegovo mesto.

\section{Literatura}

Erl, V. Dž. Uvod u filozofiju, Dereta, Beograd, 2005.

Kagan, S. Normative Ethics, Westview Press, Boulder, 1998.

Nozick, R. Anarchy, State, Utopia, Basic Books, New York, 1974.

Nozick. R. Philosophical Explanations, Harvard University Press, Cambridge, 1981. THE INFLUENCE OF ETHICS COURSES ON THE MORAL 


\section{INTUITIONS OF PHILOSOPHY STUDENTS}

Abstract: In this paper, we analyze part of the research conducted within the project "The impact of philosophy courses on students' attitudes" which concerns the impact of History of Ethics courses on the moral intuitions of second-year philosophy students at the Faculty of Philosophy in Nis. Students evaluated the statements given in a specially designed questionnaire on two occasions (before and after listening to the courses). By analyzing possible changes in the answers given by the students, we try to determine whether the courses they have attended in the meantime have led to a significant change in their moral intuitions.

Keywords: ethics, moral intuitions, research, teaching 